\title{
Investigation of the Boundary between Abderaz and Kalat Formations Based on Calcareous Nannofossils in West Kopet-Dagh (NE IRAN)
}

\author{
Mohammad Anvar Moheghy ${ }^{*}$, Fatemeh Hadavi, Behname Rahimi \\ Department of Geology, Faculty of Science, Ferdowsi University of Mashhad, Mashhad, Iran \\ Email: *moheghy@gmail.com
}

Received February 26, 2013; revised March 26, 2013; accepted April 26, 2013

Copyright (c) 2013 Mohammad Anvar Moheghy et al. This is an open access article distributed under the Creative Commons Attribution License, which permits unrestricted use, distribution, and reproduction in any medium, provided the original work is properly cited.

\begin{abstract}
The biostratigraphy of calcareous nannofossils of the Cretaceous is investigated in the boundary between Abderaz and Kalat Formations through the record of species richness, diversity and distribution patterns in the west Kopet-Dagh region. The Kalat Formation comprising of coarse-grained detritus limestone with subordinate sandstone intercalations and the Abderaz Formation mainly consists of limestone, Shale and Limy marl. Nannofossils of this boundary in each of studied sections are listed and figured. 21 species in Ghalehzoo section, 29 species in Sheikh section and 19 species in Jozak section have been determined. Boistratigraphy based on calcareous nannofossil allow the identification of nannofossil standard zones CC21 and CC26 in all of sections, According to these zones in all of sections, the age of the studied thickness is Early Late Campanian-Late Late Maastrichtian in these sections.
\end{abstract}

Keywords: Nannofossils; Biostratigraphy; Abderaz; Kalat; Iran; Kopet Dagh

\section{Introduction}

The investigation of calcareous nannofossil assemblages from the boundary of Aberaz and Kalat Formations allowed for the testing of nannofossil biozonation schemes and will be used to document the biostratigraphical changes throughout the late Cretaceous of the Kopet Dagh basin.

The sediments are preserved and including several species recently described from the upper boundary of Abderaz Formation and lower boundary of Kalat Formation in west Kopet Dagh that have not been recorded previously from these regions (Figure 1). The aim of this study is to provide a catalogue of the species encountered in this boundary to serve as a guide for future studies in this area.

\section{Geological Setting}

Kopet Dagh has a complete Cretaceous sedimentary succession comprising marine shales, marly limestone and subordinate sandstones. This sequence seems to represent all stages of the Cretaceous [1,2].

\footnotetext{
"Corresponding author.
}

The Abderaz Formation is composed of light gray to grayish white shale and three to four chalky limestone beds.

Abderaz Formation is exposed in vast area in KopetDoghrange. An indication of thickness increases of Abderaz Formation in the eastern Kopet-Dogh from $500 \mathrm{~m}$ in the southern (Shurijeh) to $1500 \mathrm{~m}$ in the northest (Taherabad) [1].

The Kalat Formation is a unit of limestone contains subordinate sandstones intercalation and is conformably interbedded between the Abderaz Formation below and Nafteh Formation above. Thicknesses of this formation decrease from east to west of Kopet Dagh [3].

As it is shown in Figure 2, four biozones of CC22CC25 are missed in all three sections the reason for that could possibly be related to the disconformity between Kalat and Abderaz formations. According to the Stocklin 1968, the Abderaz formation is overlaid by Abtalkh and this formation is covered by Neyzar formation in the east of Kopet-Dagh, as all these two formations are missed in these three studied sections. We can conclude that the contact between Abderaz and Kalat formations would be unconformable as discussed previously by Afshar-Harb 


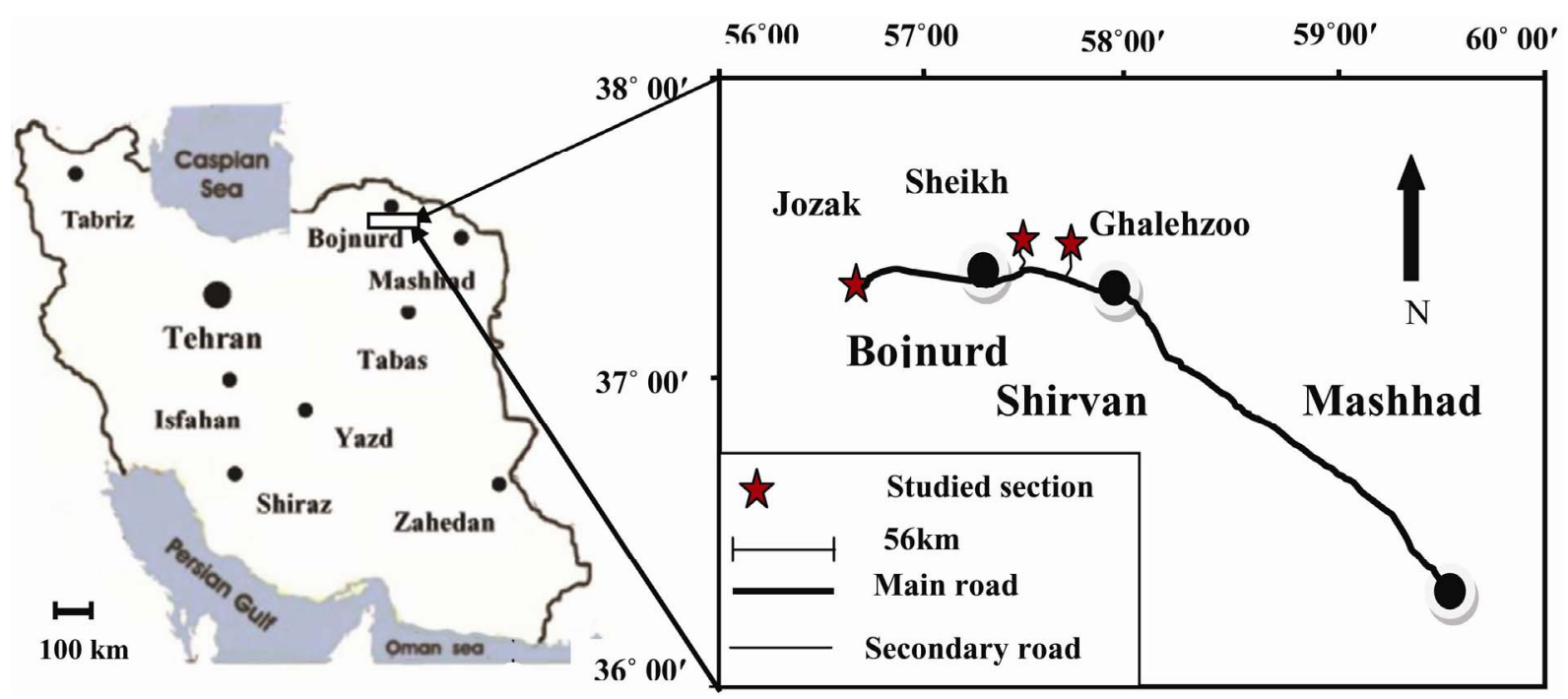

Figure 1. Geographical situation of studied sections.

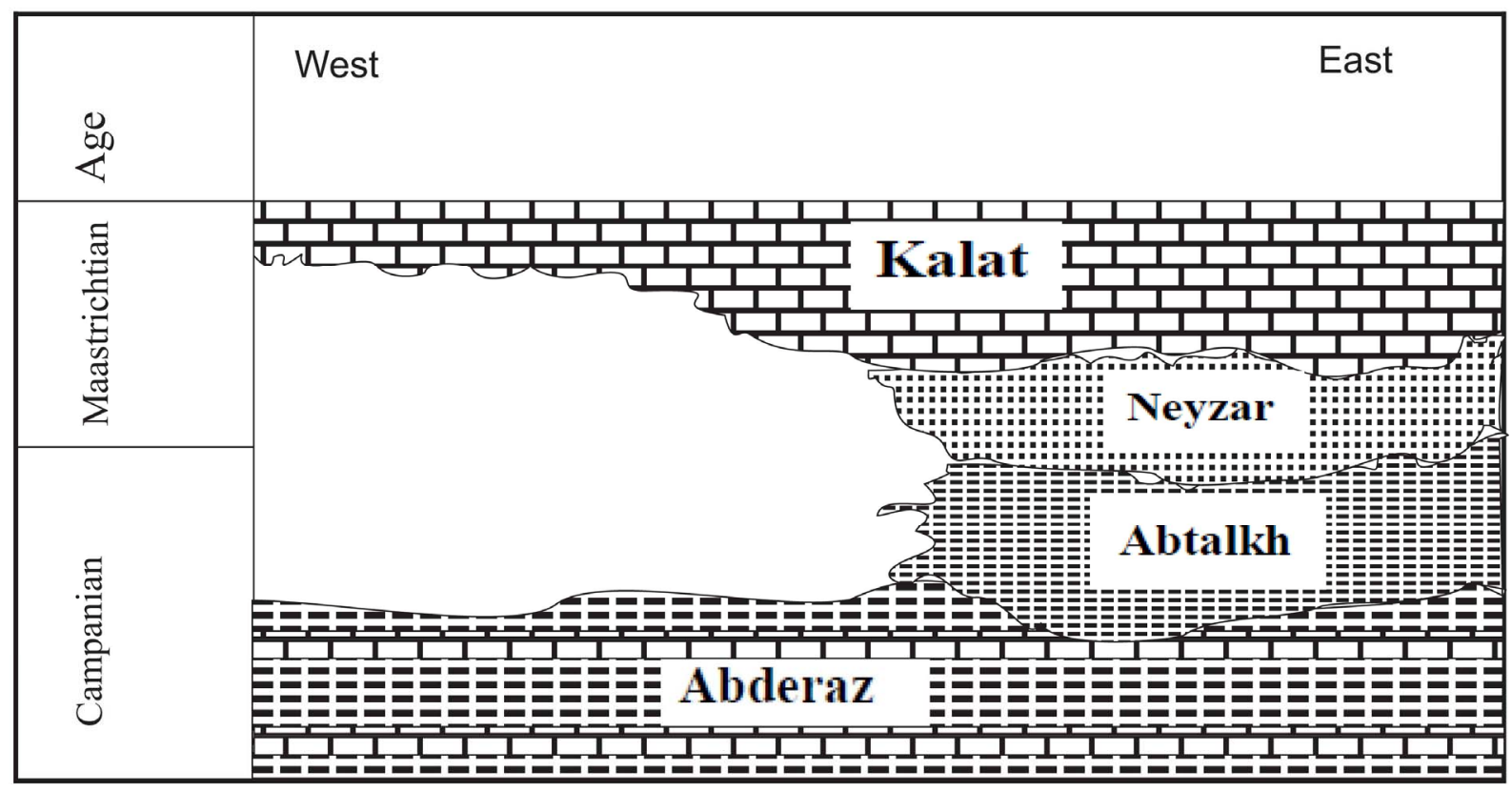

Figure 2. Disconformity between Kalat and Abderaz formations in the west of Kopet Dagh.

[4]; the lack of Abtalkh Formation in the west of KopetDagh could possibly be related to the disconformity that happened after sedimentation of Abderaz formation. Stocklin [1] also reported that in the west of Kopet-Dagh Kalat formation overlie Abderaz formation. According to these observations we conclude that there has been a probable disconformity between Kalat and Abderaz formations in all three studied sections in the west of KopetDagh.

In this study samples from the upper part of Abderaz Formation and lower part of Kalat Formation in Ghalehzoo, Sheikh and Jozak sections were taken. The sampling was done with the thickness of 30 meters and contained lime- stone, Shale, Limy marl and sandy limestone (Figure 3).

\section{Samples and Methods}

A total of twelve samples of this boundary was collected. Samples were collected at about 2.5-m intervals around the boundary. Nannofossils with smear-slides were prepared following the standard procedure [5] for this, the surface of each sample was scraped with a razor blade until a fresh surface was obtained, and then, a small amount of sediment was scraped onto a glass coverslip and diluted with distilled water. The suspension was smeared with a flat-sided toothpick along the surface of the coverslip and then dried on a hot plate. Between 


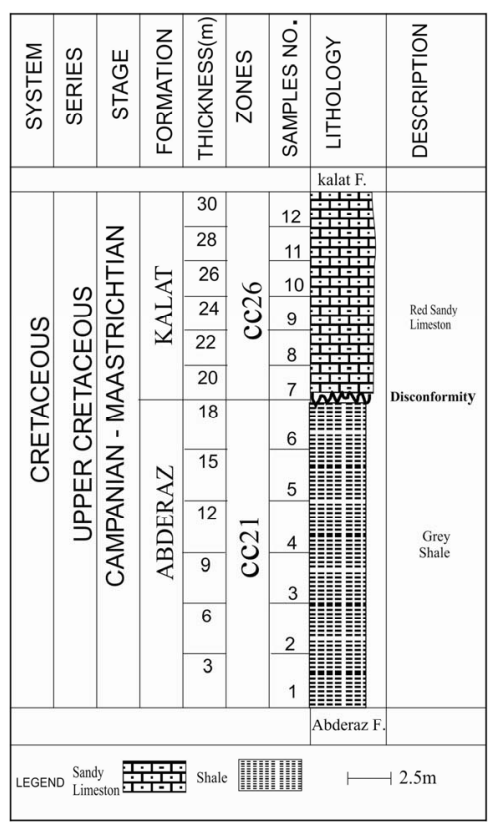

(a) Sheikh section

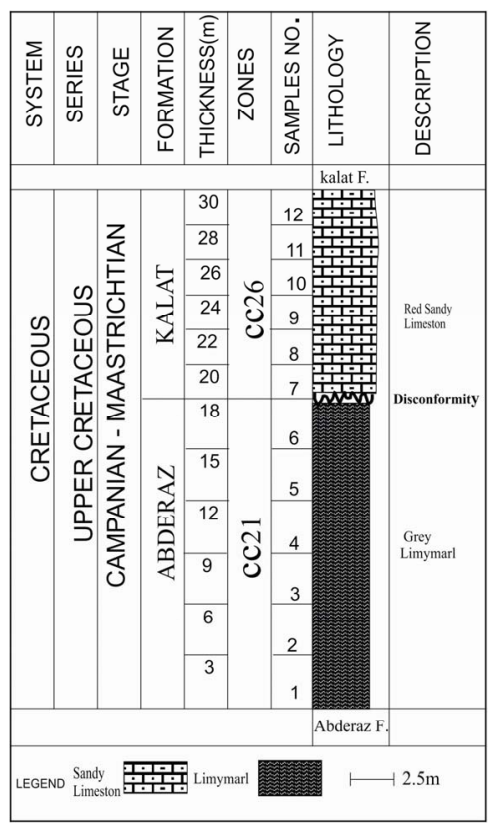

(b) Ghalehzoo section

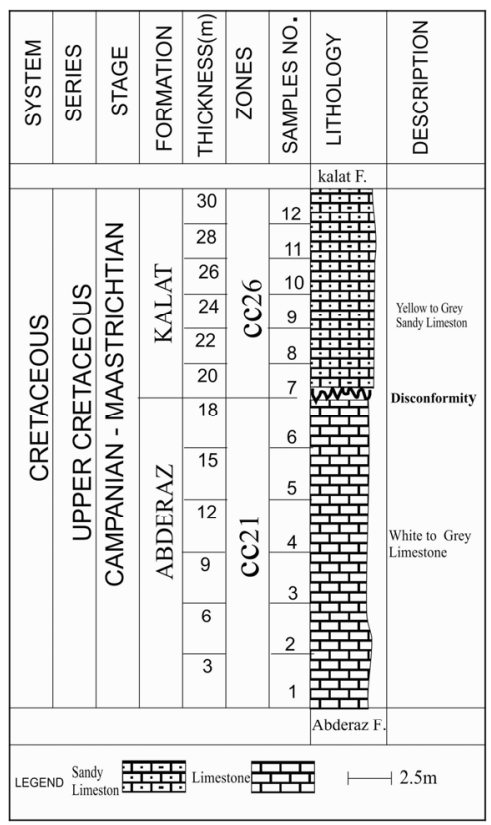

(c) Jozak section

Figure 3. (a) Lithostratigraphic column of the boundary between Abderaz and Kalat Formations in Sheikh section; (b) Lithostratigraphic column of the boundary between Abderaz and Kalat Formations in Ghalehzoo section; (c) Lithostratigraphic column of the boundary between Abderaz and Kalat Formations in Jozak section.

preparations, the razor blade was washed in distilled water. The counter and the hot plate were cleaned with $10 \%$ $\mathrm{HCl}$ between sample preparations. This was done to reduce the chance of contamination. The twelve samples were examined on a light-polarized microscope BH2 model and photographed with a digital camera (Plates 1-3); in these plates "Gh" in Ghalehzoo section and, "Sh" in Sheikh section and " $\mathrm{J}$ " is as a picture of fossil in Jozak section).

All calcareous nannofossils specimens encountered, were identified following the taxonomic schemes of several renowned authors [6-14].

The earliest biostratigraphical studies of the Cretaceous formations of the Kopet Dagh and particularly of Abderaz and Kalat Formations have been focused on the base on foraminifera e.g. Afshar Harb [15] Some sedimentology investigation has been done too.

The previous nannofossils studies of Abderaz and Kalat Formations were by Hadavi and Moheghy [16], Hadavi and Notghi Moghaddam [17,18] and Moheghy and Hadavi [19].

All of previous studies, were inclusive study of whole formations especially investigation of biostratigraphy in the east, but in the present study for the first time biostratigraphy of the boundary between Abderaz and Kalat Formations in west Kopet-Dagh were discussed.

\section{Calcareous Nannofossil Preservation}

In the studied samples, all specimens in west are well to moderately preserved, showing a slight degree of etching and overgrowth.

In the Maastrichtian, the most resistant taxon to dissolution is Micula decussate but Micula murus has a much lower ratio of resistance to [20]. The abundance of Watznaueria barnesae also considered as a solution-resistant species, though with a lower ratio of resistance to dissolution than M. decussata [20].

Hence a visual evaluation of etching and overgrowth using a light microscope was performed to specify the preservation state of the counted assemblages following the method of Bown and Young [5].

In the present samples structures of central area of hetercoccoliths were identified, therefore in this boundary, diagenetic processes did not profoundly alter the original nannofossil assemblages.

\section{Nannofossils Diversity and Abundance}

In the studied sections, 21 species in Ghalehzoo section, 29 species in Sheikh section and 19 species in Jozak section were identified (Tables 1-3). In this boundary diversity tends to increase toward up section, patterns of abundances as well as diversity indices can be interpreted as a reflection of original paleoecological conditions.

The abundance of samples varies, for example Watznaueria barnesae toward up section decrease and Micula decussata from base to top, increase. Some species belonging to the genera Zeugrhabdotus and Tranolithus occurred only sporadically with relatively low percentage. 


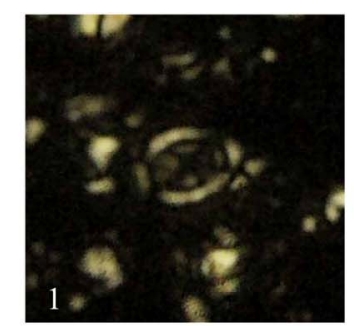

Arkhangelskiella specillata Image \# Abderaz4 (Sh)

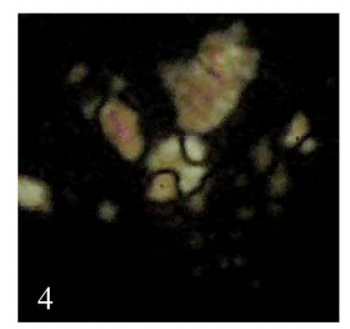

Calculites obscurus Image \# Abderaz 3 (Gh)

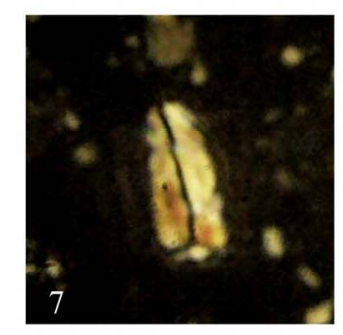

Lucianorhabdus cayeuxii Image \# Abderaz 6 (Sh)

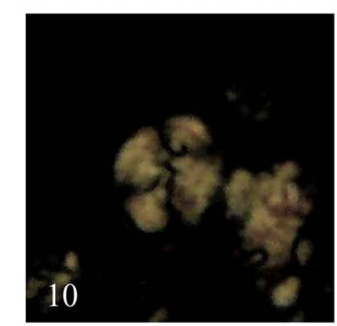

Watznaueria barnesae Image \# Abderaz 3 (J)

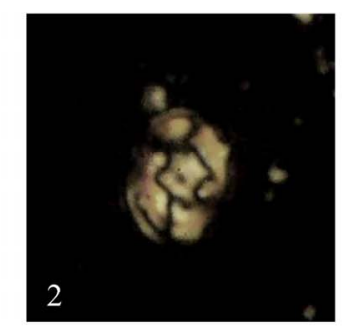

Zeugrhabdotus embergeri Image \# Abderaz 6 (Gh)

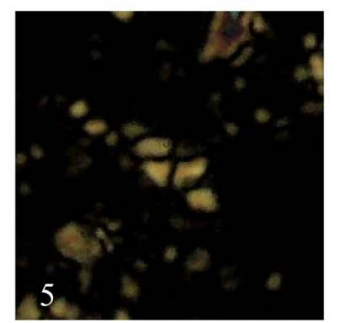

Calculites ovalis

Image \# Abderaz 4 (J)

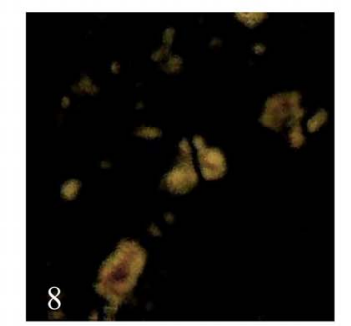

Lucianorhabdus maleformis Image \# kalat9 (Gh)

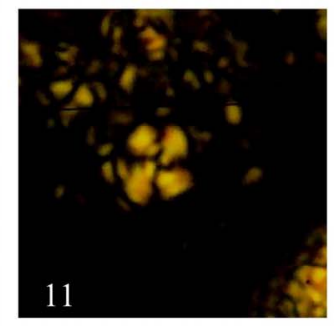

Watznaueria biporta

Image \# Abderaz 4 (J)

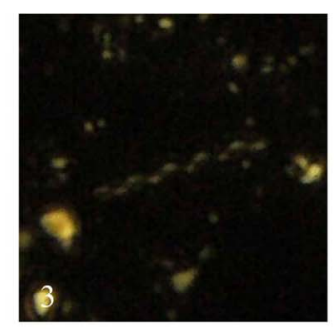

Microrhabdulus decoratus Image \# Abderaz 4 (Sh)

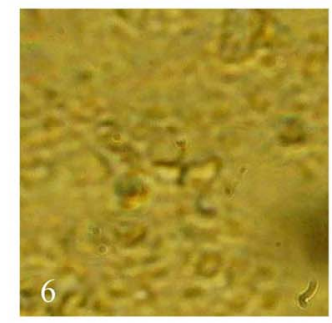

Calculites ovalis

Image \# Abderaz 4 (J)

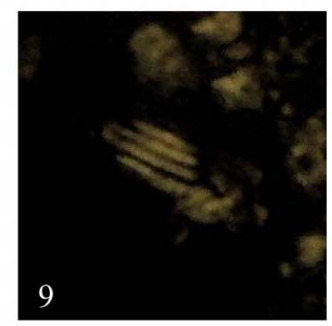

Calcicalathina alta Image \# kalat 8(J)

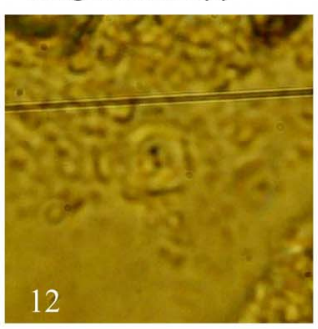

Watznaueria biporta Image \# Abderaz 4 (J)

Plate 1. All figures, light micrographs magnified $\times \mathbf{2 5 0 0}$.

In the studied sections Quadrum spp. has the most abundant in the first samples while Micula prinsii identified only from uppermost of this sections.

Other taxa such as Braarudosphaera spp., Calcicalathina alta, Acuturris scouts, Eiffellithus spp. are present in these samples in much lower abundances.

\section{Biostratigraphy and Zonation}

The studied interval spans the calcareous nannofossil zones CC21 and CC26 of Sissingh [20] that modified and illustrated in Perch-Nielsen [9].
These biozones cover the EarlyLate Campanian to Late Late Maastrichtian. The proposed biozones are arranged from base to top and they are Quadrum sissinghii and Nephrolithus frequens zones.

\subsection{Quadrum Sissinghii Zone (CC21)}

The Quadrum sissinghii zone was proposed by Sissingh [21]. The age of this zone is Early Late Campanian. Sissingh [21] suggested that this zone is identified from the first occurrence Qudrum sissinghii to Fo Qudrum trifidium. 


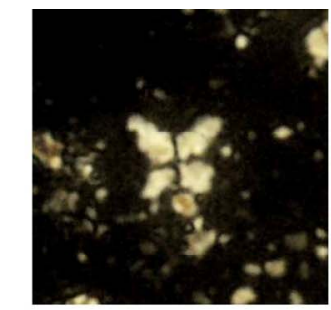

Quadrum sissinghii

Image \# Abderaz. 1 (Sh)

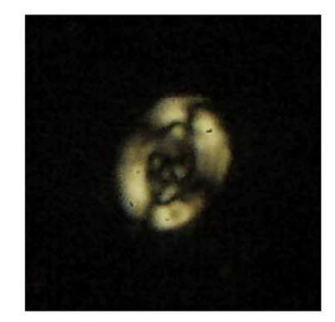

Aspidolithus parcus parcus Image \# Abderaz 5 (Sh)

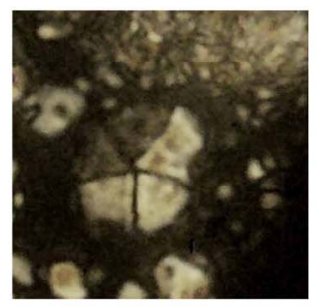

Braarudosphaera bigelowii Image \# Abderaz 3 (Gh)

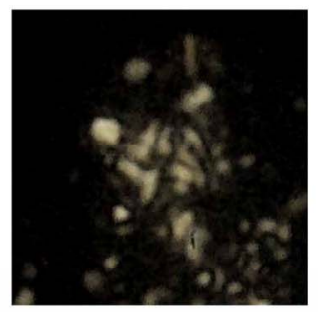

Micula swastica Image \# Kalat $10(\mathrm{~J})$

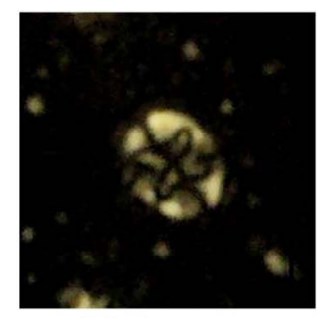

Eiffellithus gorkae Image \# Kalat 8 (J)

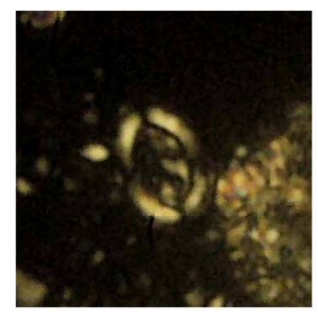

Aspidolithus parcus expansus Aspidolithus parcus constrictus Image \# Kalat 8 (J)

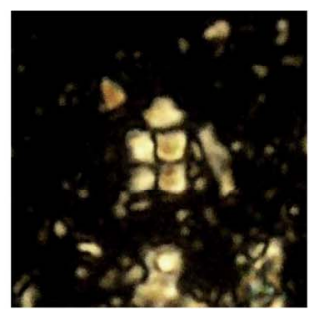

Quadrum gothicus Image \# Kalat 8 (Gh)

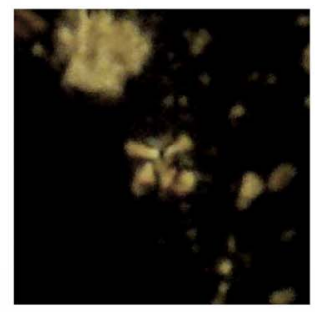

Micula prinsii Image \# Kalat 7 (Gh)

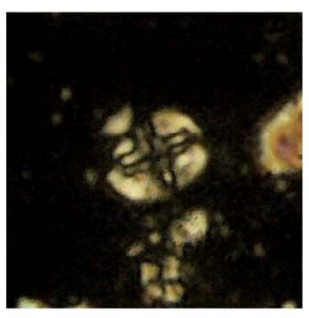

Eiffellithus eximius Image \# Abderaz 2 (Sh)

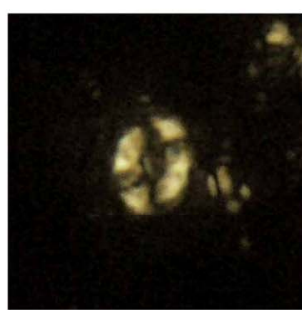

Image \# Abderaz 4 (Sh)

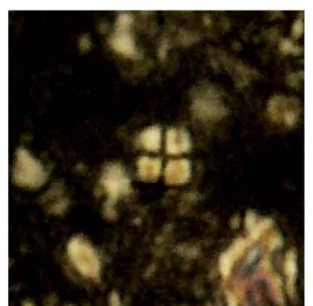

Quadrum gartneri Image \# Kalat 12(J)

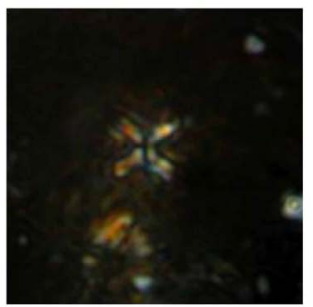

Micula decussata Image \# Kalat $11(\mathrm{~J})$

Plate 2. All figures, light micrographs magnified $\times \mathbf{2 5 0 0}$.

This zone is suggested for the upper part of Abderaz Formation in Jozak, Ghalehzoo and Sheikh sections and it is dominated besides the marker species by Lucianorhabdus cayeuxii-Lucianorhabdus maleformis-Watznaueria barnesae-Watznaueria biporta-Micula decussate-Eiffellithus gorkae-Eiffellithus turriseiffelii-Quadrum gothicusQuadrum gartneri.

\subsection{Nephrolithus Frequens Zone (CC26)}

This zone is proposed by Cepek and Hay [6]. The age of this zone is Late Late Maastrichtian. It includes the interval from Fo to Lo $N$. frequens in high latitude but in low latitude Fo M. murus or Fo Micula prinsii can be used to determine the upper boundary of this zone. The most dominant species in this zone addition to the marker species are Lucianorhabdus cayeuxii-Eiffellithus gorkaeEiffellithus turriseiffelii-Quadrum gothicus-Lithraphidites carniolensis-Lithraphidites quadratus-Micula murus-Micula premurus-Micula decussate-Micula prinsii-Watznaueria barnesae.

Base on the calcareous nannoplankton zones, especially lack of CC22-CC23-CC24 and CC25 between the uppermost of Abderaz Formation and lower part of Kalat Formation, a discontinuous sedimentary sequence across the Abderaz and Kalat Formations boundary were suggested. 


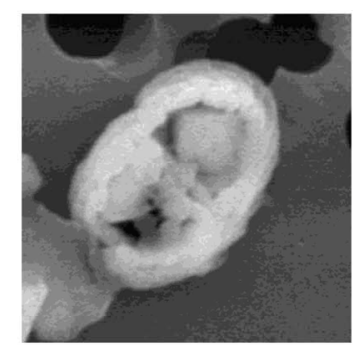

Zeugrhabdotus erectus Image \# Abderaz 1 (Sh)

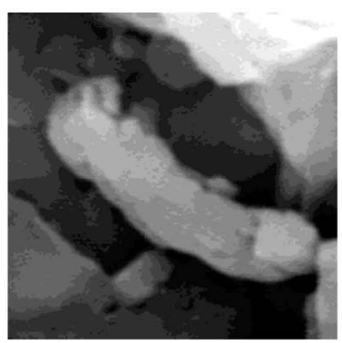

Lucianorhabdus cayeuxii Image \# Abderaz 4 (Sh)

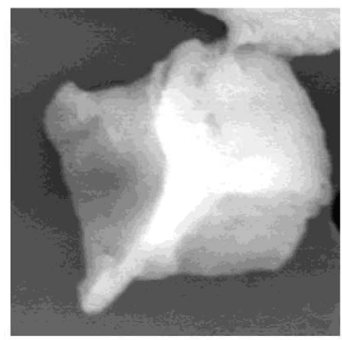

Micula decussata Image \# Abderaz 3(Sh)

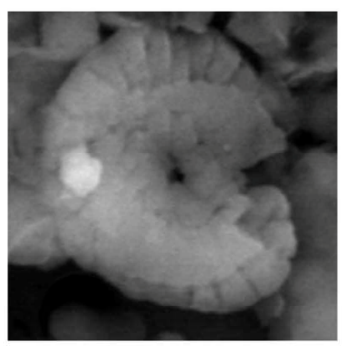

Watznaueria barnesae Image \# Abderaz 6 (J)

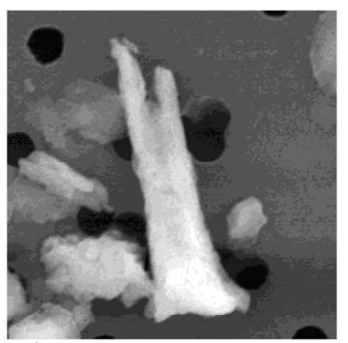

Acuturris scotus Image \# Abderaz 1 (Sh)

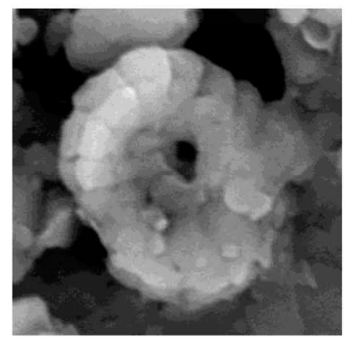

Watznaueria biporta Image \# Kalat $12(\mathrm{~J})$

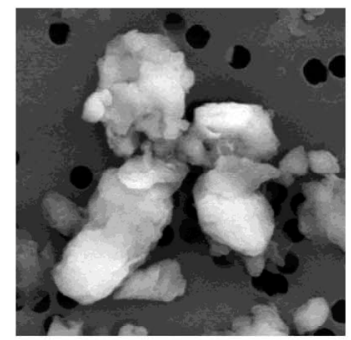

Uniplanarius sissinghii Image \# Abderaz 6 (Sh)

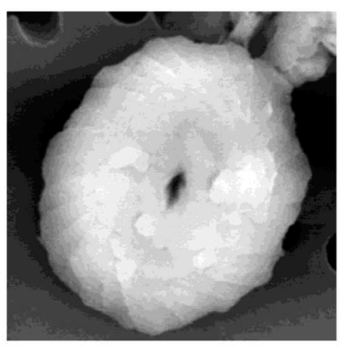

Watznaueria barnesae Image \# Abderaz 5 (Sh)

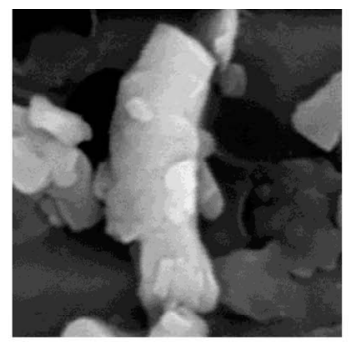

Lucianorhabdus cayeuxii Image \# Kalat 7 (J)

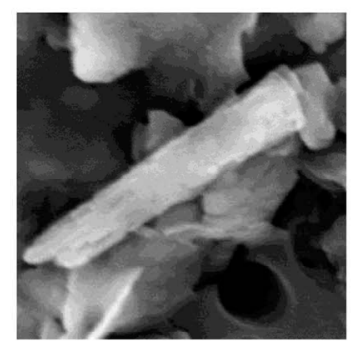

Lithraphidites carniolensis Image \# Abderaz 1 (Gh)

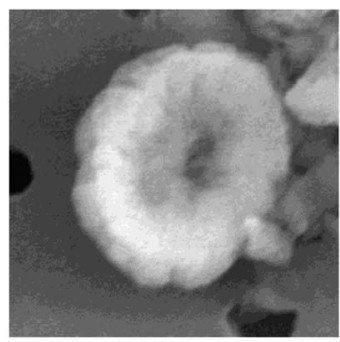

Watznaueria barnesae Image \# Abderaz 2 (Gh)

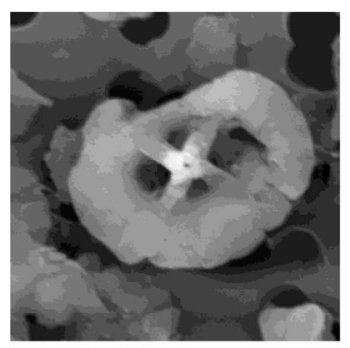

Eiffellitus turriseiffelii Image \# Abderaz 2 (Sh)

Plate 3. All figures, electronic micrographs magnified $\times \mathbf{1 5 , 0 0 0}$.

\section{Conclusions}

The nannofossil assemblages of the boundary between Abderaz and Kalat Formations are relatively medium in abundant and diversity with well to moderate preservation. In this study, 21 species in Ghalehzoo section, 29 species in Sheikh section and 19 species in Jozak section were recognized. Absolute abundances of upper calcare- ous nannofossils allowed us to infer the biozonation and record local bioevents in this boundary.

In these sections, Base on calcareous nannofossils, the age of the studied sections is Early Late Campanian-Late Late Maastrichtian. According to this investigation and base on the calcareous nannoplankton zones, especially lack of CC22-CC23-CC24 and CC25 between the uppermost of Abderaz Formation and lower part of Kalat 
Table 1. Distribution of calcareous nannofossils in the boundary between Abderaz and Kalat Formations from the Sheikh section.

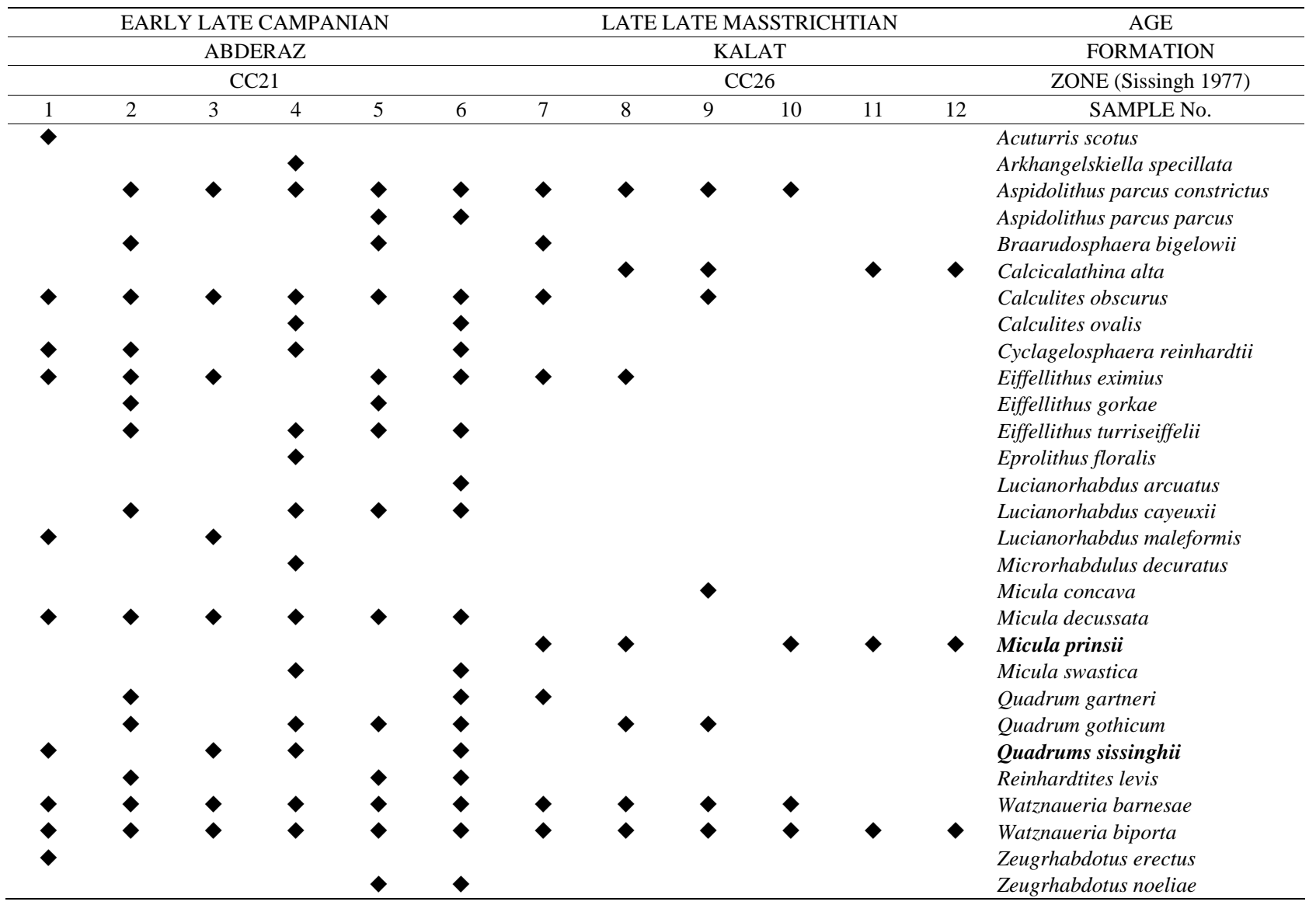

Table 2. Distribution of calcareous nannofossils in the boundary between Abderaz and Kalat Formations from the Ghalehzoo section.

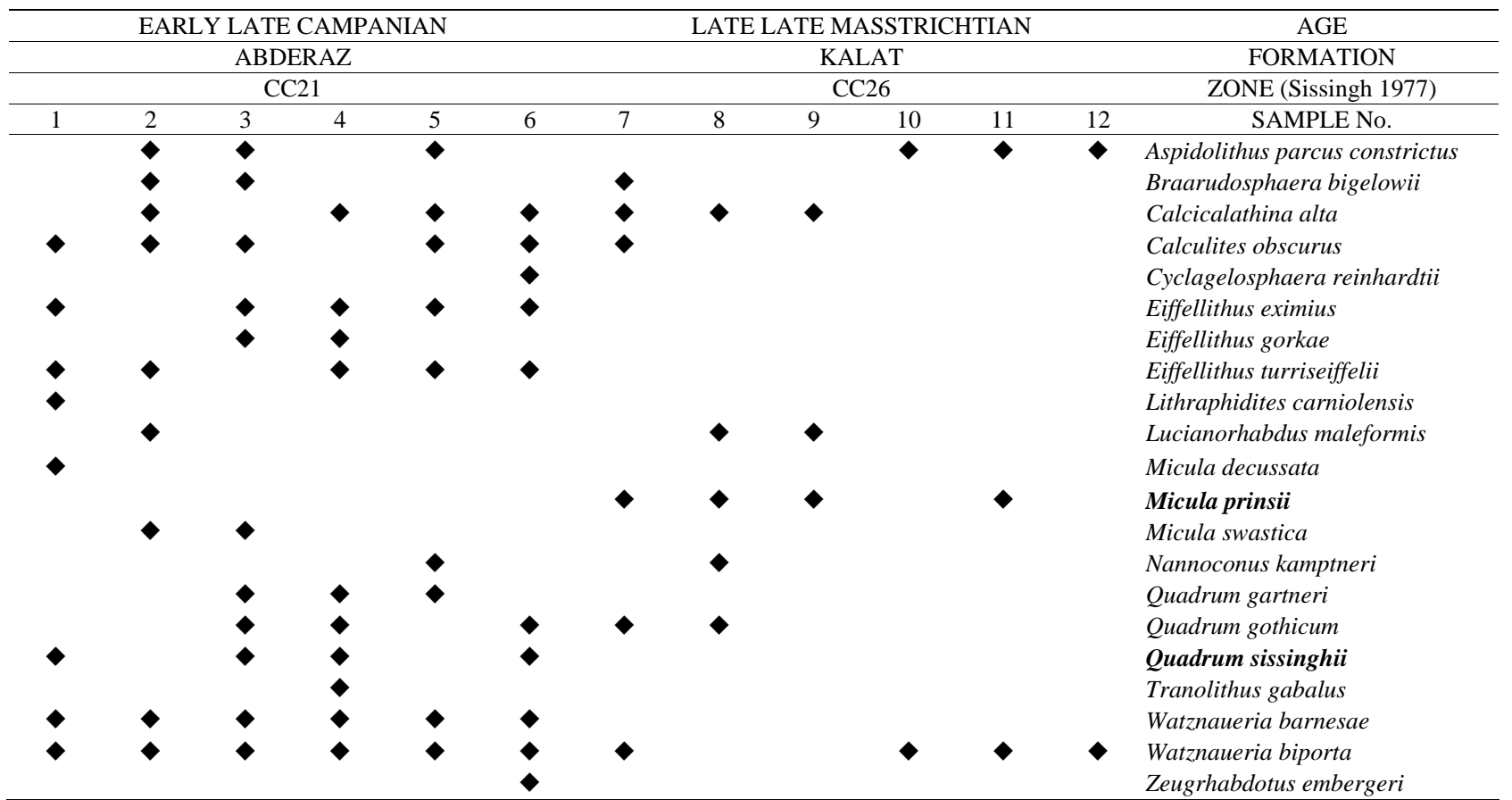


Table 3. Distribution of calcareous nannofossils in the boundary between Abderaz and Kalat Formations from the Jozak section.

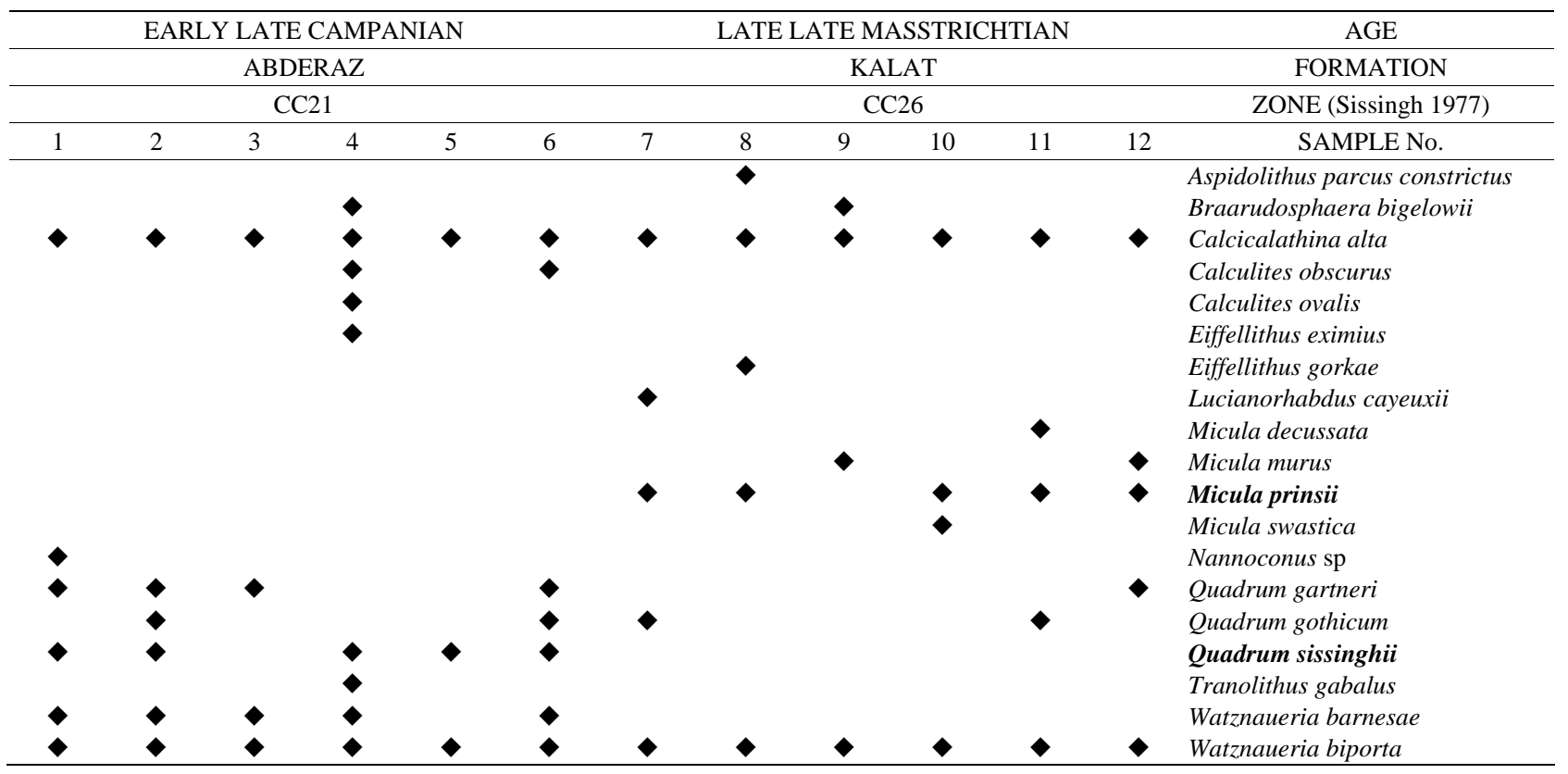

Formation, a discontinuous sedimentary sequence across the Abderaz and Kalat Formations boundary were determined.

\section{REFERENCES}

[1] J. Stöcklin, "Structural History and Tectonics of Iran: A Review,” AAPG Bulletin, Vol. 52, No. 7, 1968, pp. 12291258.

[2] A. Afshar-Harb, “A Brief History of Geological Exploration and Geology of the Sarakhs Area and the Khangiran Gas Field,” Bulletin of the Iranian Petroleum Institute, Vol. 37, 1969, pp. 86-96.

[3] J. Stocklin, "Stratigraphic Lexicon of Iran," Ministry of Industry and Mines, Geological Survey of Iran, Teheran, 1971.

[4] A. Afshar-Harb, "Geology of Kopet Dagh,” In: A. HushMandzadeh, Ed., Treatise on the Geology of Iran, Geological Survey of Iran, Tehran, 1994. (In Persian)

[5] P. R. Bown and J. R. Young, “Techniques,” In: P. R. Bown, Ed., Calcareous Nannofossil Biostratigraphy, Chapman \& Hall, London, 1998, pp. 16-28. doi:10.1007/978-94-011-4902-0 2

[6] P. Cepek and W. W. Hay, "Calcareous Nannoplankton and Biostratigraphic Subdivision of the Upper Cretaceous," Gulf Coast Association of Geological Societies Transactions, Vol. 19, No. 2, 1969, pp. 323-336.

[7] H. R. Thierstein, "Mesozoic Calcareous Nannoplankton Biostratigraphy of Marine Sediments," Marine Micropaleontology, Vol. 1, No. 2, 1976, pp. 325-362. doi:10.1016/0377-8398(76)90015-3

[8] K. Perch-Nielsen, "Recognition of Cretaceous Stage Boundaries by Means of Calcareous Nannofossils,” In: T.
Birkelund, R. Bromley, W. K. Christensen, E. Håkansson and F. Surlyk, Eds., Symposium on Cretaceous Stage Boundaries, Copenhagen, 1983, pp. 152-156

[9] K. Perch-Nielsen, "Mesozoic Calcareous Nannofossils," In: H. M. Bolli, J. B. Saunders and K. Perch-Nielsen, Eds., Plankton Stratigraphy, Cambridge University Press, Cambridge, 1985, pp. 329-426.

[10] J. R. Williams and T. J. Bralower, "Nannofossil Assemblages, Fine Fraction Stable Isotopes, and the Paleoceanography of the Valanginian-Barremian (Early Cretaceous) North Sea Basin,” Paleoceanography, Vol. 10, No. 4, 1995, pp. 815-839. doi:10.1029/95PA00977

[11] S. Gardin, "Late Maastrichtian to Early Danian Calcareous Nannofossilsat Elles (Northwest Tunisia). A Tale of One Million Years across the K-T Boundary,” Palaeogeography, Palaeoclimatology, Palaeoecology, Vol. 178, No. 3-4, 2002, pp. 211-231. doi:10.1016/S0031-0182(01)00397-2

[12] J. A. Burnett, "Upper Cretaceous,” In: P. R. Bown, Ed., Calcareous Nannofossil Biostratigraphy, Chapman and Hall, London, 1998, pp. 132-199.

[13] J. L. Shamrock and D. K. Watkins, "Evolution of the Cretaceous Calcareous Nannofossil genus Eiffellithus and Its Biostratigraphic Significance,” Cretaceous Research, Vol. 30, No. 5, 2009, pp. 1083-1102. doi:10.1016/j.cretres.2009.03.009

[14] N. Thibault and S. Gardin, "Maastrichtian Calcareous Nannofossil Biostratigraphy and Paleoecology in the Equatorial Atlantic (Demerara Rise, ODP Leg 207 Hole 1258A)," Revue de Micropaléontologie, Vol. 49, No. 4, 2006, pp. 199-214. doi:10.1016/j.revmic.2006.08.002

[15] A. Afshar-Harb, "The Stratigraphy, Tectonics and Petroleum Geology of the Kopet Dagh Region, Northern Iran,” Ph.D. Thesis, University of London, London, 1979. 
[16] F. Hadavi and M. A. Moheghy, "Biostratigraphic Study of the Calcareous Nannoplanktons of Kalat City and Chahchaha Village,” Geosciences, Vol. 12, No. 55, 2005, pp. 42-53. (Text in Persian, Abstract in English)

[17] F. Hadavi and M. N. Moghaddam, "Calcareous Nannofossils from Chalky Limestone of Upper Abderaz Formation and Lower Part of Abtalkh Formationin the KopetDogh Rang NE Iran,” Arabian Journal of Geoscience, Vol. 3, No. 7-8, 2010, pp. 52-61. doi:10.1007/s12517-009-0106-5

[18] F. Hadavi and M. N. Moghaddam, "Nannostratigraphy, Nannofossil Events, and Paleoclimate Fluctuations in the Lower Boundary of Kalat Formation in East Kopet Dagh (NE Iran),” Arabian Journal of Geoscience, Vol. 5, No. 6,
2012, pp. 50-65. doi:10.1007/s12517-012-0802-4

[19] M. A. Moheghy and F. Hadavi, "Nanostratigraphy and Sedimentology of the Abderaz Formation at Sheikh Section (Western Kopet-Dagh Basin),” Journal of Applied Geology, Vol. 8. No. 2, 2012, pp. 59-172. (Text in Persian, Abstract in English)

[20] H. R. Thierstein, "Selective Dissolution of Late Cretaceous and Earliest Tertiary Calcareous Nannofossils: Experimental Evidence,” Cretaceous Research, Vol. 1, No. 2, 1980, pp. 165-176. doi:10.1016/0195-6671(80)90023-3

[21] W. Sissingh, "Biostratigraphy of Cretaceous Calcareous Nannoplankton,” Geologie en Minjbouw, Vol. 56, No. 1, 1977, pp. 37-65. 